\title{
Mycobiota of asparagus vigna seeds (Vigna unguiculata (L.) Walp.) on the south of Western Siberia
}

\author{
Yury $V$. Fotev, ${ }^{1.2^{*}}$ and Olga $A$. Kazakova ${ }^{2}$ \\ ${ }^{1}$ Central Siberian Botanical Garden SB RAS, Novosibirsk 630090, ul. Zolotodolinskaya 101, Russia \\ ${ }^{2}$ Novosibirsk State Agrarian University, Novosibirsk 630039, ul. Dobrolyubova, 160, Russia
}

\begin{abstract}
Composition of seed mycobiota of 87 accessions of asparagus vigna (Vigna unguiculata (L.) Walp.) from the N. I. Vavilov All-Russian Institute of Plant Genetic Resources (VIR) and the Bioresource Scientific Collection of the Central Siberian Botanical Garden (CSBG SB RAS) UNU No.USU 440534 have been investigated on 2018-2019. Seeds of accessions were grown on the south of Western Siberia $\left(54^{\circ} \mathrm{N}\right.$ lat. $\left.83^{\circ} \mathrm{E}\right)$ in the unheated plastic film greenhouse and examined for fungal microbiota in the Central Siberian Botanical Garden and Novosibirsk State Agrarian University (Novosibirsk). The seed infestation of micromycetes was determined according to GOST 12044-93 (similar to common beans) using the methods of mycological analysis and the Petri dish moist chambers, also on Chapek and KDA media. The following pathogens were assigned to the permanent inhabitants of mycocenosis of asparagus vigna seeds: Fusarium spp., Mucor mucedo, Penicillium spp., Rhizopus spp., Aspergillus niger, to the occasional - Alternaria spp. Botritis sinerea and Sclerotinia sclerotiorum occur moderately and intermittently in the samples of vigna seeds. The highest frequency of occurrence and infestation of asparagus vigna seeds were found for Aspergillus niger (minmax: $30-100 \%$ and $0-100 \%$, respectively), the minimum for Alternaria spp. $(0-10 \%)$.
\end{abstract}

\section{Introduction}

Vigna or asparagus vigna (Vigna unguiculata (L.) Walp. (Fabaceae) is a new for the Russia thermophilic vegetable crop [1]. Sibirskiy razmer and Yunnanskaya were the first Russian cultivars of this crop created in the Central Siberian Botanical Garden SB RAS by 2006. Now the list of vigna cultivars registered in the State Register of Selection Achievements in Russia expanded to 25 varieties (2019). The increase in production, monoculture, the development of new regions (ecological niches) for growing asparagus vigna naturally raise the question for study of seed contamination by mycopathogens.

Given the lack of information of fungi composition on the asparagus vigna seeds in Siberia we attempted to fill this gap. The purpose of the work is to determine the

${ }^{*}$ Corresponding author: fotev_2009@mail.ru 
composition of micromycetes and the degree of infestation of asparagus vigna seeds grown in the unheated plastic film greenhouse in the south of Western Siberia.

\section{Materials and methods}

Asparagus vigna seeds were grown in the unheated plastic film greenhouse of the Central Siberian Botanical Garden SB RAS (CSBG) in the south of Western Siberia $\left(54^{\circ} \mathrm{N}, 83^{\circ}\right.$ E) in 2018-2019. Laboratory experiments were carried out in Lab. for the introduction of food plants of CSBG and Lab. of phytosanitary diagnostics and prognosis of Novosibirsk State Agrarian University. We used 87 accessions of $V$. unguiculata from the N.I.Vavilov Institute of Plant Genetic Resources (VIR) and and the Bioresource Scientific Collection of the Central Siberian Botanical Garden (CSBG SB RAS) UNU No.USU 440534.

Contamination of cowpea seeds with pathogenic micromycetes was determined according to GOST 12044-93 (similar to common bean) by the methods of mycological analysis and the "wet chamber". Mycological analysis of seeds was carried out on universal Chapek nutrient media and KDA in 4-6-fold repetition. The media were prepared according to GOST 12044-93. To assess the pathogenic mycocenosis of vigna seeds we used the Jaccard's coefficient $(\mathrm{K})$ that is an indicator of the number of common characters in the compared phytocenoses and other taxa [2]. $\mathrm{K}=\mathrm{C} /(\mathrm{A}+\mathrm{B})-\mathrm{C}$, where $\mathrm{K}$ is the Jaccard coefficient; $\mathrm{A}$ is the number of species at the first test site, $\mathrm{B}$ is the number of species at the second test site, $\mathrm{C}$ is the number of species common to the 1 st and 2 nd sites. When $\mathrm{K}$ is close to unity, the similarity of species is maximal, and when $\mathrm{K}$ is close to zero, it is minimal.

\section{Results and discussion}

In 2018 freshly harvested vigna seeds were contaminated by 8 species of micromycetes (Table 1).

Table 1 Composition of micromycetes of freshly harvested asparagus vigna seeds

\begin{tabular}{|l|c|c|}
\hline Species & $\begin{array}{c}\text { Frequency of occurrence } \\
\text { (min } \div \max ), \%\end{array}$ & $\begin{array}{c}\text { Infestation (min } \div \max ), \\
\%\end{array}$ \\
\hline Alternaria spp. & $0 \div 1,0$ & $0 \div 10.0$ \\
\hline Aspergillus niger Tiegh. & $30.0 \div 100.0$ & $0 \div 100.0$ \\
\hline Botrytis cinerea Pers. & $0 \div 30.0$ & $0 \div 50.0$ \\
\hline Fusarium spp. & $0 \div 80.0$ & $0 \div 80.0$ \\
\hline Mucor mucedo Sowerby & $0 \div 90.0$ & $0 \div 40.0$ \\
\hline Penicillium spp. & $0 \div 90.0$ & $0 \div 40.0$ \\
\hline Rhizopus spp. & $0 \div 90.0$ & $0 \div 30.0$ \\
\hline Sclerotinia sclerotiorum (Lib.) de Bary & $0 \div 30.0$ & $0 \div 40.0$ \\
\hline
\end{tabular}

The highest frequency of occurrence and infection of seeds were found for Aspergillus niger (30-100\% and $0-100 \%$, respectively), the minimum for Alternaria spp. (0-10\%). The following pathogens were assigned to the permanent inhabitants of mycocenosis of vigna seeds: Fusarium spp., Mucor mucedo, Penicillium spp., Rhizopus spp., Aspergillus niger, to random - Alternaria spp. Botritis sinerea and Sclerotinia sclerotiorum occur moderately and intermittently in the sampes of vigna seeds.

The species Sclerotinia sclerotiorum was first noted as a pathogen of asparagus vigna in Russia. However, according to GOST 12044-93, there is the possibility of transmitting this pathogen through the seeds of beans, peas and soy. In available foreign and Russian literary sources this species on cowpea seeds has not been previously described. After a long-term 
storage (13 years) vigna seeds were infected by Aspergillus niger on 100\%. All other mycopathogens during prolonged storage probably died. For example, according to V.A. Chulkina [3], fungi of the genus Fusarium persist on seeds for about 5 years.

In the mass of grown seeds of Vigna unguiculata we detected seeds with obvious symptoms of a seed infection. Seeds with signs of pathogen damage that had been laid on wet filter paper on the 5th day showed mycelial growth of mycobiota and sporulation of individual species (Fig.1).

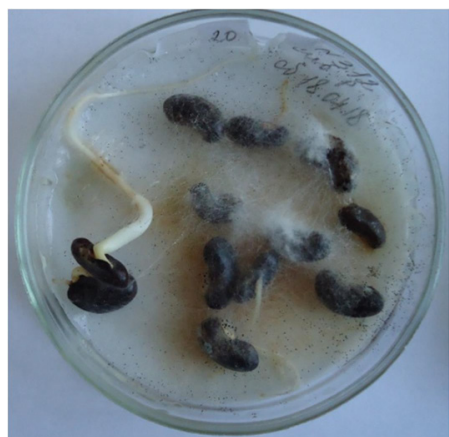

a

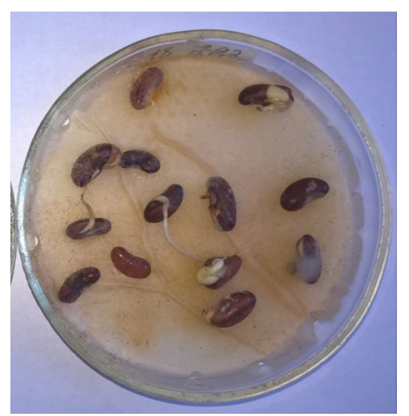

$\mathrm{b}$

Fig.1 Seeds of $V$. unguiculata cultivars - Sibirskiy razmer (a) and Yunnanskaya (b) with symptoms of damage by micromycetes and sporulation of individual species.

The causative agents of mold are often manifested in explicit form under adverse fruit ripening and storage conditions (elevated temperature and humidity), Fusarium spp. - with high contamination of seeds and plants during the growing season.

We also conducted a comparative analysis of contamination of cowpea seeds in different regions of the world. Summarized data are presented in table 2.

Table 2. The species composition of mycobiota in the south of Western Siberia, Russia and other regions of the world

\begin{tabular}{|c|c|c|c|c|c|c|}
\hline Species & $\begin{array}{c}\text { India } \\
{[4]}\end{array}$ & $\begin{array}{c}\text { South } \\
\text { Africa [5] }\end{array}$ & $\begin{array}{c}\text { Nigeria } \\
\text { [6] }\end{array}$ & Botswana [7] & $\begin{array}{c}\text { Kazakhstan } \\
{[8]}\end{array}$ & $\begin{array}{c}\text { south of } \\
\text { Western } \\
\text { Siberia } \\
\text { (authors' } \\
\text { data) }\end{array}$ \\
\hline $\begin{array}{l}\text { Aspergillus } \\
\text { spp. }\end{array}$ & + & + & + & + & + & + \\
\hline A. flavus & + & + & & + & + & \\
\hline A. niger & + & + & + & + & & + \\
\hline A. ochraceus & & + & & & & \\
\hline A. terreus & + & & & & & \\
\hline A. fumigatus & + & & & & + & \\
\hline $\begin{array}{l}\text { Penicillium } \\
\text { spp. }\end{array}$ & & + & & + & + & + \\
\hline P. chrisogenum & & & & + & + & \\
\hline P.rugulosum & 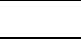 & & & & + & \\
\hline Alternaria spp. & + & + & & & + & + \\
\hline $\begin{array}{l}\text { Alternaria } \\
\text { alternata }\end{array}$ & + & & & & + & \\
\hline Rhizopus spp. & + & & & & + & + \\
\hline $\begin{array}{l}\text { Rhizopus } \\
\text { nigricans }\end{array}$ & & & & & + & \\
\hline
\end{tabular}




\begin{tabular}{|l|l|l|l|l|l|l|}
\hline $\begin{array}{l}\text { Rhizopus } \\
\text { stolonifer }\end{array}$ & & & + & + & & + \\
\hline $\begin{array}{l}\text { Rhizopus } \\
\text { oligosporus }\end{array}$ & & & & + & & \\
\hline Mucor mucedo & & & & & + & + \\
\hline $\begin{array}{l}\text { Botrytis } \\
\text { cinerea }\end{array}$ & & & & & + & + \\
\hline $\begin{array}{l}\text { Macrosporium } \\
\text { commune }\end{array}$ & & & & & + & \\
\hline $\begin{array}{l}\text { Botryodiplodia } \\
\text { theobromae }\end{array}$ & & & + & + & + & + \\
\hline Fusarium spp. & + & & + & + & + & \\
\hline $\begin{array}{l}\text { Fusarium } \\
\text { oxysporum }\end{array}$ & + & & + & & & \\
\hline $\begin{array}{l}\text { Fusarium } \\
\text { equiseti }\end{array}$ & & & & & & \\
\hline $\begin{array}{l}\text { Drechslera } \\
\text { tetramera }\end{array}$ & + & & & & & \\
\hline $\begin{array}{l}\text { Cylindrocarpon } \\
\text { sp }\end{array}$ & & & & & & \\
\hline $\begin{array}{l}\text { Macrophomina } \\
\text { phaseolina }\end{array}$ & + & & & & & \\
\hline $\begin{array}{l}\text { Sclerotinia } \\
\text { sclerotiorum }\end{array}$ & & & & & & \\
\hline
\end{tabular}

Note: + the disease occurs, ++ the disease is described on the seeds of $V$. unguiculata for the first time.

The Jaccuard similarity coefficient showed that the species composition of asparagus vigna seeds in the Siberia is the closest to the species composition of fungal infections in $\operatorname{Kazakhstan}(\mathrm{K}=0.41)$ and varies quite significantly with other regions $(\mathrm{K}=0.3$ and less $)$.

In 2018, the verification of the sowing quality of seeds of vigna cultivars $(n=12)$ showed the presence of a significant $(p<0.001)$ negative correlation between the number of seeds affected by micromycetes and germination index/germination rate, respectively, $\mathrm{r}=$ -0.928 and -0.935 .

Therefore, the highest frequency of occurrence and infestation of asparagus vigna seeds were found for Aspergillus niger (min-max: 30-100\% and 0-100\%, respectively), the minimum for Alternaria spp. (0-10\%). The following pathogens were assigned to the permanent inhabitants of mycocenosis of the seeds: Fusarium spp., Mucor mucedo, Penicillium spp., Rhizopus spp., Aspergillus niger, to the occasional - Alternaria spp. Botritis sinerea and Sclerotinia sclerotiorum are moderately and inconstantly found in lots of asparagus vigna seeds. The species Sclerotinia sclerotiorum was first noted as a pathogen of asparagus vigna in Russia when conducting a study in the Central Siberian Botanical Garden. The Jaccard similarity coefficient showed that species of mycobiota on asparagus vigna seeds in the south of Western Siberia is closest to the species composition of seed fungal infections in Kazakhstan $(\mathrm{K}=0.41)$ and varied quite significantly with other regions ( $\mathrm{K}=0,3$ and less). This can be explained by different weather conditions and crop growing conditions in various regions of the world.

\section{References}

1. Y.V Fotev, A.I.Syso, O.M. Shevchuk Current Challenges in Plant Genetics, Genomics, Bioinformatics, and Biotechnology, in Proceedings of the 5th International Scientific

Conference, 24-29 June, 2019, Novosibirsk, Russia, 12-14 (2019) 
2. R. Real, J.M. Vargas, Systematic Biology, 45, 380-385 (1996)

3. V.A. Chulkina Agrotechnical method of plant protection (ITC Marketing, Moscow, 2000)

4. K. I. Vasava, V. R. Gohel, K. D. Vaghela, Trends in Biosciences, 10, 6414-6417 (2017)

5. Q. Kritzinger, Storage fungi and mycotoxins associated with cowpea seed (MSc thesis, U of Pretoria, Pretoria, 2000)

6. N. G. Iyanyi, A. E. Ataga, I. A. Nwaukwu, Niger. J. Mycol., 7, 85-92 ( 2015)

7. K.B.Khare, D. Loeto, K.Wale, M. Salani, Intern. J. Bioassays, 5, 5021-5024 (2016)

8. Bostanova AM, Abdrashitov A. A. Proc. Nat. Acad. Sci. of Kazakhstan, Biol.and Med. Series., 2, 60-64 (2012) 